\title{
Egyptian Journal of Botany

Evaluation of Biochar as a Soil Amendment for Alleviating the Harmful Effect of Salinity on Vigna unguiculata (L.) Walp

Mohamed E.H. Osman ${ }^{(1)}$, Awatif A. Mohsen ${ }^{(1)}$, Afaf A. Nessem ${ }^{(1) \#}$, Mohamed S. El-sakka ${ }^{(2)}$ and Walaa A. Mohamed ${ }^{(1)}$

(1)Botany Department, Faculty of Science, Tanta University, Tanta, Egypt; (2)Soil, Water and Environment Research Institute (S.W.E.R.I.), Sakha, Kafr El-Sheikh, Egypt.

$\mathbf{T}$

HE EXPERIMENT was conducted to investigate the effects of application of rice straw waste-derived biochar on the growth and some metabolic activities of salt-stressed cowpea (Vigna unguiculata L.). Moreover, biochar as a soil amendment was evaluated with the additional rate of chemical fertilizers (NPK) under salinity stress in agro-ecosystem. The results indicate that salinity $(200 \mathrm{mM} \mathrm{NaCl})$ caused a significant reduction in all measured growth parameters of cowpea seedlings compared with control. Salinity stress caused reduction in germination percentage by $54 \%$ and $14 \%$ and $17 \%$ in the lengths of shoot and root, respectively as well as leaf area (22\% reduction), compared with the control. Furthermore, the activities of antioxidant enzymes (peroxidase, catalase and superoxide dismutase), malondialdehyde (MDA), ascorbic acid content and osmolytes (total soluble proteins, carbohydrates and amino acids) were increased under salinity stress. The results showed that application of rice straw-derived biochar increased the germination percentage and all the studied growth criteria under salinity stress. In addition, rice straw-derived biochar increased the photosynthetic activity and photosynthetic pigments (Chl. $a$, Chl. $b$ and carotenoids) and decreased the biosynthesis of MDA and ascorbic acid. The results demonstrate that the highest values of the measured growth parameters and physiological processes of cowpea seedlings were recorded at $75 \%$ NPK combined with biochar treatment. In conclusion, application of rice straw-derived biochar reduced the additional rate of chemical fertilizer by $25 \%$.

Keywords: Biochar, Chemical fertilizer, Cowpea, Photosynthesis, Salinity.

\section{Introduction}

As a major agricultural problem, soil salinity is one of the most abiotic stresses that affect arable land in arid regions. More than 800 million hectares of the total land surface suffer from soil salinization, which significantly affect growth and crops productivity (Yun et al., 2018). Salinity results in ion toxicity, osmotic and oxidative stress, nutritional imbalances, reduction of cell division and alterations in plant metabolic processes as photosynthesis, respiration, and disorganization of cell membranes (Hasanuzzaman et al., 2014).

Black carbon manufactured through pyrolysis of biomass 'biochar' is a stable organic material prepared under limited oxygen supply; it has been utilized for the improvement of soil fertility and reduction of abiotic and biotic stresses such as salinity stress, heavy metals and drought stress (Ali et al., 2017).

Biochar enhances soil water holding capacity and plant production under limited water supply (Zong et al., 2016). Furthermore, it supplies reduced trace element toxicity in plants and increase metal immobilization in the soil (Abbas et al., 2017).

Therefore, the aim of the current study is to evaluate the role of biochar as soil amendment on growth and some metabolic activities of salinity

"Corresponding author email: afaf_nessim@yahoo.com

Received 16/12/2018; Accepted 16/4/2019

DOI: $10.21608 /$ ejbo.2019.6709.1267

Edited by: Prof. Dr. Hosam Esa Elsaied, National Institute of Oceanography, NIOF, Egypt.

(C)2019 National Information and Documentation Center (NIDOC) 
stressed Vigna unguiculata (L.) and to investigate its role in reducing the amount of chemical fertilizers (NPK) used in agriculture nowadays.

\section{Materials and Methods}

\section{Materials}

The seeds of cowpea (Vigna unguiculata L. cv. Careem) were obtained from Agriculture Research Center, Seeds Department, Sakha Research Station, Kafr El-Sheikh, Egypt.

Rice straw-derived biochar processing and analysis

The biomass of rice straw was collected from farms in Kafr El-sheikh and processed in Soil, Water and Environment Research Institute (S.W.E.R.I.), Sakha Research Station, Kafr El-Sheikh. The material was thoroughly dried in the sun and converted to biochar using oven at $300^{\circ} \mathrm{C}$ pyrolysis temperature according to the recommendation of Lehmann \& Joseph (2015). Thereafter, biochar was crushed and sieved through a $2 \mathrm{~mm}$ sieve then grinded and stored.

Chemical fertilizer (NPK) was obtained from Soil, Water and Environment Research Institute (S.W.E.R.I.), Sakha Research Station, Kafr ElSheikh.

\section{Soil analysis}

Soil was collected and estimated in the Soil, Water and Environment Research Institute., Sakha Research Station, Kafr El-Sheikh. Soil was dried in an electric oven, whereas $\mathrm{EC}$ and $\mathrm{pH}$ were measured with conductivity $(\mathrm{mS} / \mathrm{cm})$ by $\mathrm{pH}$ meter. The total organic matter and organic carbon were determined according to the methods described by Blume (1990) and Nelson \& Sommers (1996). Soil minerals $(\mathrm{mg} / \mathrm{kg})$ were analyzed according to Allen et al. (1974).

\section{Preliminary experiment}

This experiment was carried out to determine the lethal and sub-lethal concentrations of $\mathrm{NaCl}$ and to determine the best dose of chemical fertilizer (NPK) that can alleviate the salinity stress. Different concentrations of $\mathrm{NaCl}$ were prepared $(0,50,100$, $150,200,250$ and $300 \mathrm{mM}$ ) for determination of the lethal and sub lethal concentration of $\mathrm{NaCl}$. Different doses of chemical fertilizer were used $\left(50 \%, 75 \%\right.$ and $100 \%$ NPK; $200 \mathrm{~kg} \mathrm{ha}^{-1} \mathrm{~N}$ (Ammonium sulphate), $300 \mathrm{~kg} \mathrm{ha}^{-1} \mathrm{P}$ (calcium super phosphate) and $150 \mathrm{~kg} \mathrm{ha}^{-1} \mathrm{~K}$ (Potassium sulfate), according to the dose recommended by the Ministry of Agriculture.

\section{Experimental design}

According to the results of a preliminary experiment, the sub-lethal concentration of $\mathrm{NaCl}$ $(200 \mathrm{mM})$ and the best chemical fertilizer dose that could alleviate salinity $(75 \%)$ were used in the main experiment. This experiment was conducted in the greenhouse of Botany department, Faculty of Science, Tanta University. The experiments were carried out during the growing season of cowpea, i.e. from $1^{\text {st }}$ April to 30 June under normal environmental conditions $\left(32 \pm 2^{\circ} \mathrm{C}\right.$ during the day and $22 \pm 2^{\circ} \mathrm{C}$ during the night).

Two groups of pots were prepared; each group was represented by twelve plastic pots $(25 \mathrm{~cm}$ diameter and $30 \mathrm{~cm}$ depth). Three pots for each subgroup and each one contained $5 \mathrm{~kg}$ clay-sandy soil $(2: 1 \mathrm{w} / \mathrm{w})$. Ten seeds were sown in each pot. The first group had the soil without any additions and was divided into four subgroups, the $1^{\text {st }}$ subgroup had the soil only (control), the $2^{\text {nd }}$ was the salinity treatment $(200 \mathrm{mM} \mathrm{NaCl})$, the $3^{\text {rd }}$ had soil supplemented with biochar and the $4^{\text {th }}$ one had soil supplemented with biochar and thereafter treated with salinity stress. The second group had the soil mixed with chemical fertilizer (75\% NPK) and was also divided into four subgroups as the previous arrangement. At the $8^{\text {th }}, 12^{\text {th }}$ and $16^{\text {th }}$ days of sowing, seedlings were irrigated with $200 \mathrm{mM}$ $\mathrm{NaCl}$ solution. Pots were irrigated up to $80 \%$ field capacity with tap water or $\mathrm{NaCl}$ solution $(200 \mathrm{mM})$ for 21 days (seedling stage). The seedlings were separated into shoots and roots for carrying out the measurements of growth parameters (shoot length, root length, leaf area, fresh and dry weights of shoot and root).

\section{Physiological analysis}

\section{Photosynthetic activity and pigments}

Photosynthetic activity was measured as fluorescence emission of dark-adapted leaves, using OS-30p chlorophyll fluorometer (Hudson, NH 03051 USA). The photosynthetic pigments, chlorophyll $a$ (Chl. $a$ ), chlorophyll $b$ (Chl. $b$ ) and carotenoids were assayed according to Arnon (1949) and expressed as mg.g.-1 DW.

\section{Enzymes extraction and assays}

A sample of $0.5 \mathrm{~g}$ fresh leaves was frozen and then homogenized in $8 \mathrm{ml}$ of $50 \mathrm{mM}$ cold phosphate buffer (pH 7.0) (Beauchamp \& Fridovich, 1971). The homogenates were centrifuged at 4000rpm 
at $4^{\circ} \mathrm{C}$ for $20 \mathrm{~min}$. The supernatant was used as a raw extract for enzymatic assay. Activities of catalase (CAT) [EC1.11.1.6] and peroxidase (POX) [EC1.11.1.7] were assayed according to Kato \& Shimizu (1987). Activity of superoxide dismutase (SOD) [EC 1.151.1] was assayed according to Beyer \& Fridovich (1987). Enzyme activity was expressed as $\mu \mathrm{M}$ substrate converted per min. per gram fresh weight.

\section{Lipid peroxidation and ascorbic acid content}

Lipid peroxidation level was measured by determining malondialdehyde (MDA) content (peroxidation product) according to Heath \& Packer (1968), calculated using the extinction coefficient $\left(155 \mathrm{mM}^{-1} \mathrm{~cm}^{-1}\right)$ and expressed as $\mu \mathrm{mol} \mathrm{g}^{-1}$ f. wt. Ascorbic acid was estimated according to Oser (1979) and calculated as mg $\mathrm{g}^{-1}$ f. wt. by using a calibration curve.

\section{Total soluble protein and carbohydrates}

The phenol-sulfuric acid method has been used to estimate the total soluble carbohydrates using a calibration curve according to Dubois et al. (1956). Total soluble protein content was estimated quantitatively using phosphate buffer extract ( $\mathrm{pH} 7$ ) and a calibration curve by Bovine serum albumin (BSA) as a standard protein according to Bradford (1976). The results are expressed as $\mathrm{mg} \mathrm{g}^{-1} \mathrm{DW}$.

\section{Total amino acids and proline content}

Amino acid content was assayed in leaves using ninhydrin and glycine as a standard according to Lee \& Takahashi (1966). Proline was estimated according to Zunigam et al. (1989) and Bates (1973) by using toluene as a blank. They are calculated as $\mathrm{mg} \mathrm{g}^{-1} \mathrm{DW}$.

\section{Statistical analysis}

Statistical analysis was carried out according to the method of complete randomized blocks design using analysis of variance and the significance was determined using L.S.D. values at $\mathrm{P}=0.05$ and 0.01 according to Snedecor \& Cochran (1980). The results were analyzed statistically using one-way (ANOVA) test to determine the degree of significance. The analysis was carried out using COSTAT statistical program.

\section{Results}

Analysis of soil and rice straw-derived biochar

Data shown in Table 1 indicate the physical and chemical analysis of soil. The results indicate that the soil has low concentrations of available microelements such as $\mathrm{Cu}^{+2}$ and $\mathrm{Zn}^{+2}$ indicating that the soil is clear and is not treated by any toxic heavy metal.

On the other hand, data in Table 2 indicate chemical and physical analysis of rice strawderived biochar and its heavy metal content. The results of mineral analysis indicate that carbon content was generally high at charring temperature $\left(300^{\circ} \mathrm{C}\right)$ and also the nitrogen content.

Germination percentage and growth criteria

Depending on the results of the preliminary experiment, the sub-lethal concentration of $\mathrm{NaCl}$ that was utilized in the main experiment was 200mM (Table 3).

TABLE 1. Chemical and physical analysis of soil.

\begin{tabular}{|c|c|c|c|c|c|c|}
\hline \multirow{3}{*}{$\begin{array}{l}\text { Physical properties } \\
\text { Dark gray color }\end{array}$} & \multicolumn{6}{|c|}{ Chemical properties } \\
\hline & \multicolumn{2}{|c|}{$\mathbf{P H}$} & O.M \% & EC mS/cm & O.C \% & МC \% \\
\hline & \multicolumn{2}{|c|}{8.0} & 0.745 & 3.5 & 1.25 & 0.005 \\
\hline \multicolumn{7}{|c|}{ Minerals analysis } \\
\hline \multicolumn{4}{|c|}{ Exchangeable Cations (mg/ kg) } & \multicolumn{3}{|c|}{ Available microelements (mg/ kg) } \\
\hline $\mathrm{Na}^{+}$ & $\mathbf{K}^{+}$ & $\mathbf{C a}^{+2}$ & $\mathrm{Mg}^{+2}$ & $\mathrm{Fe}^{+3}$ & $\mathrm{Cu}^{+2}$ & $\mathrm{Zn}^{+2}$ \\
\hline 15.3 & 0.5 & 7.1 & 3.9 & 5.3 & 0.03 & 0.22 \\
\hline
\end{tabular}

$\mathrm{EC}=$ Electrolyte conductivity, $\mathrm{O} . \mathrm{M}=$ Organic matter, $\mathrm{O} . \mathrm{C}=$ Organic carbon, $\mathrm{Na}^{+}=$Sodium ion, $\mathrm{K}^{+}=$Potassium, $\mathrm{Ca}^{+2}=\mathrm{Calcium}$ ion, $\mathrm{Mg}^{+2}=$ Magnesium, $\mathrm{Fe}^{+3}=$ Ferric ion, $\mathrm{Cu}^{+2}=$ Copper ion, $\mathrm{Zn}^{+2}=\mathrm{Zinc}$ ion. 
TABLE 2. Chemical and physical analysis of rice straw-derived biochar.

\begin{tabular}{|c|c|c|c|c|c|c|c|c|c|c|c|c|}
\hline Color & PH & $\begin{array}{c}\mathrm{EC} \mathrm{mS/} \\
\mathrm{cm})\end{array}$ & $\begin{array}{l}\text { Temp. } \\
\left({ }^{\circ} \mathrm{C}\right)\end{array}$ & $\begin{array}{c}\text { Duration } \\
\text { (hours) }\end{array}$ & WC (\%) & $\begin{array}{l}\text { Ash } \\
(\%)\end{array}$ & $\begin{array}{l}\text { OM } \\
(\%)\end{array}$ & $\begin{array}{l}\text { OC } \\
(\%)\end{array}$ & $\begin{array}{l}\text { VM } \\
(\%)\end{array}$ & $\mathrm{C}(\mathrm{g} / \mathrm{kg})$ & $\mathbf{N}(\mathrm{g} / \mathbf{k g})$ & $\mathbf{C} / \mathbf{N}$ \\
\hline Black & 6.5 & 1.38 & 300 & 4 & 0.05 & 0.54 & 0.48 & 40.5 & 11.0 & 723 & 10.5 & 68.8 \\
\hline \multicolumn{13}{|c|}{ Available microelements (mg/kg) } \\
\hline $\mathrm{Fe}^{+3}$ & & $\mathrm{Cu}^{+2}$ & $\mathbf{Z n}^{+2}$ & $\mathbf{P b}^{+2}$ & & & $\mathbf{A l}^{+3}$ & & & & $\mathbf{N i}^{+2}$ & \\
\hline 8.3 & & 0.06 & 0.5 & 0.06 & & & 0.96 & & & & 0.01 & \\
\hline
\end{tabular}

- $\mathrm{EC}=$ Electrolyte conductivity, Temp $=$ Temperature of pyrolysis, $\mathrm{WC}=$ Water content, $\mathrm{O} . \mathrm{M}=$ Organic matter, $\mathrm{O} . \mathrm{C}=$ Organic carbon, $\mathrm{V} . \mathrm{M}=$ Volatile matter, $\mathrm{C}=$ Carbon, $\mathrm{N}=$ Nitrogen, $\mathrm{C} / \mathrm{N}=$ Carbon-nitrogen ratio.

- Each value is a mean of three replicates.

TABLE 3. Effect of different concentrations of $\mathrm{NaCl}$ on germination percentage (\%) of 10-day-old Vigna unguiculata (L.) grown in clay-sandy soil $(2: 1 \mathrm{w} / \mathrm{w})$.

\section{$\mathrm{NaCl}(\mathrm{mM}) \quad$ Germination percentage $(\%)$}

\begin{tabular}{lc}
\hline 0.0 (control) & $100.0^{\mathrm{c}}$ \\
50 & $100.0^{\mathrm{c}}$ \\
100 & $63 \pm 0.1^{\mathrm{b}}$ \\
150 & $60 \pm 0.1^{\mathrm{b}}$ \\
200 & $46 \pm 0.1^{\mathrm{b}}$ \\
$250^{*}$ & 00.0 \\
$300^{*}$ & 00.0 \\
L.S.D & 18.3 \\
F-value & 46.7 \\
\hline
\end{tabular}

- The values listed are means of three replicates.

- Different letters indicate significant values at $\mathrm{P}=0.05$.

- The asterisks show salinity levels where the seeds could not survive.

The results in Table 4 demonstrate the impact of salinity stress $(200 \mathrm{mM} \mathrm{NaCl})$ on the percentage of germination and growth parameters of cowpea seedlings grown in clay-sandy soil (2:1) after the addition of biochar to the soil in presence of different concentrations of chemical fertilizers $(0 \%, 50,75$ and $100 \%$ NPK).

The results in Table 4 show that salinity stress resulted in a marked reduction in the percentage of germination $(54 \%)$ relative to the control. The results also showed that salinity reduced the values of all measured growth parameters of cowpea seedlings. In this respect, the percentage of decrease in root length, shoot height and leaf area were $14 \%, 17 \%$ and $22 \%$, respectively, compared with the control values. At the same time, the percentages of reduction in fresh weight of shoots and roots were $46 \%$ and $62 \%$, respectively, relative to the control. The dry weight of shoots and roots were also decreased by $25 \%$ and $33 \%$, respectively, compared to control.

The results (Table 4) also show that salinity stress $(200 \mathrm{mM} \mathrm{NaCl})$ with the different doses of NPK led to a significant depression in the percentage of germination and all the measured growth parameters of cowpea seedlings compared with control.

On contrary, addition of biochar to the soil under salinity stress caused a marked increase in the percentage of germination and all growth parameters, where the percentage of germination was $43 \%$ compared with the control. Treatment of cowpea seedlings with biochar under salinity stress resulted in a remarkable increase in the root length, shoot height as well as leaf area with $12 \%, 10 \%$ and $13 \%$ increases, respectively, compared with the control.

On the other hand, the combination between chemical fertilizers (NPK 75\%) with biochar resulted in the highest growth values of all the measured parameters of seedlings, compared with those of corresponding stressed plants. It was also observed that the percentage of reduction of germination percentage at the combination treatment between NPK (75\%) and $\mathrm{NaCl}(200 \mathrm{mM})$ was $44 \%$ while after the addition of biochar; the germination percentage was increased with a percentage of $30 \%$, compared with salt stressed seedlings.

\section{Photosynthetic activity (Hill reaction)}

The photosynthetic activities of the treated and untreated plants were measured as fluorescence emission (Fv/Fm), whereas, $\mathrm{Fv}=$ Variable fluorescence, $\mathrm{Fm}=$ Maximum fluorescence are presented in Fig. 1 A. 


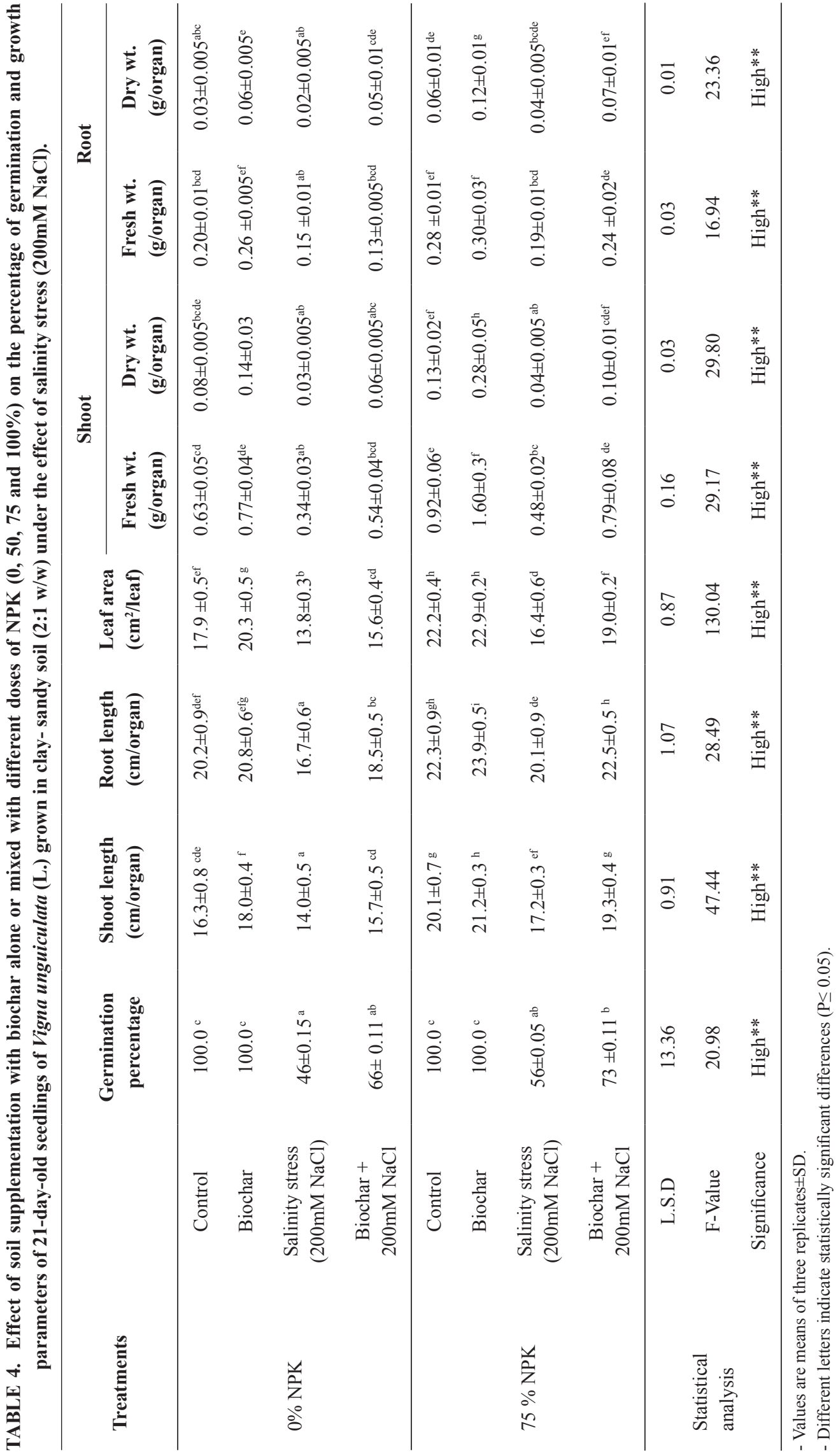

Egypt. J. Bot. 59, №.3 (2019) 
A

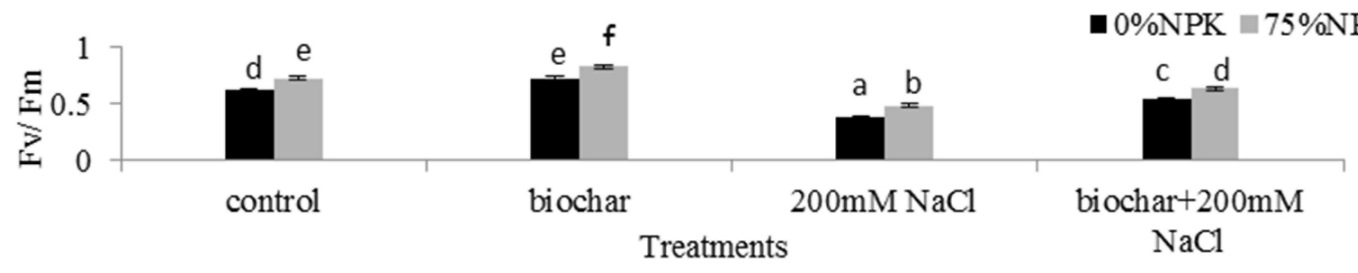

B

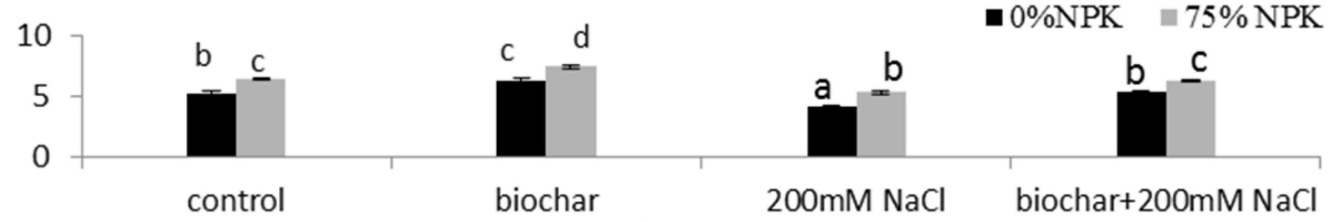

Treatments

C

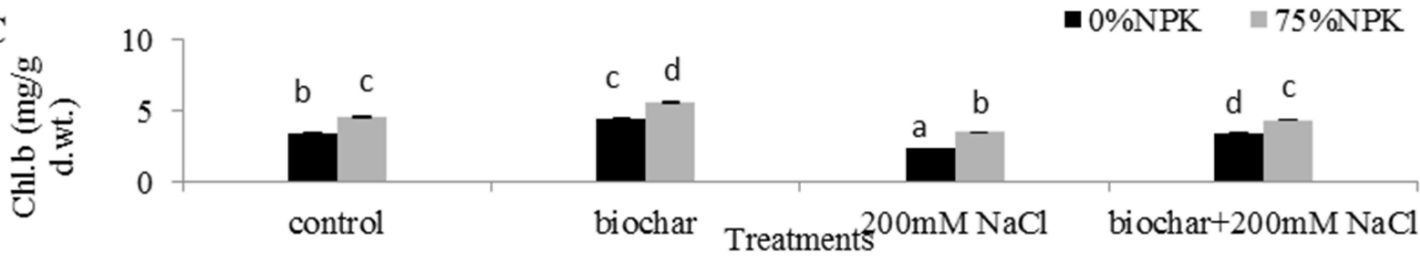

D

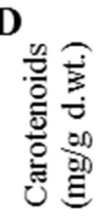
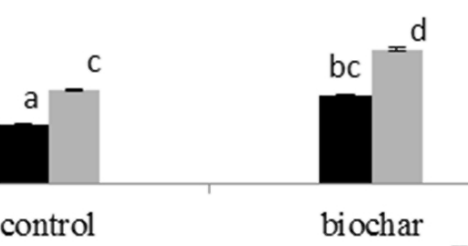

- $0 \% \mathrm{NPK}$

$=75 \% \mathrm{NPK}$

$\mathbf{E}$
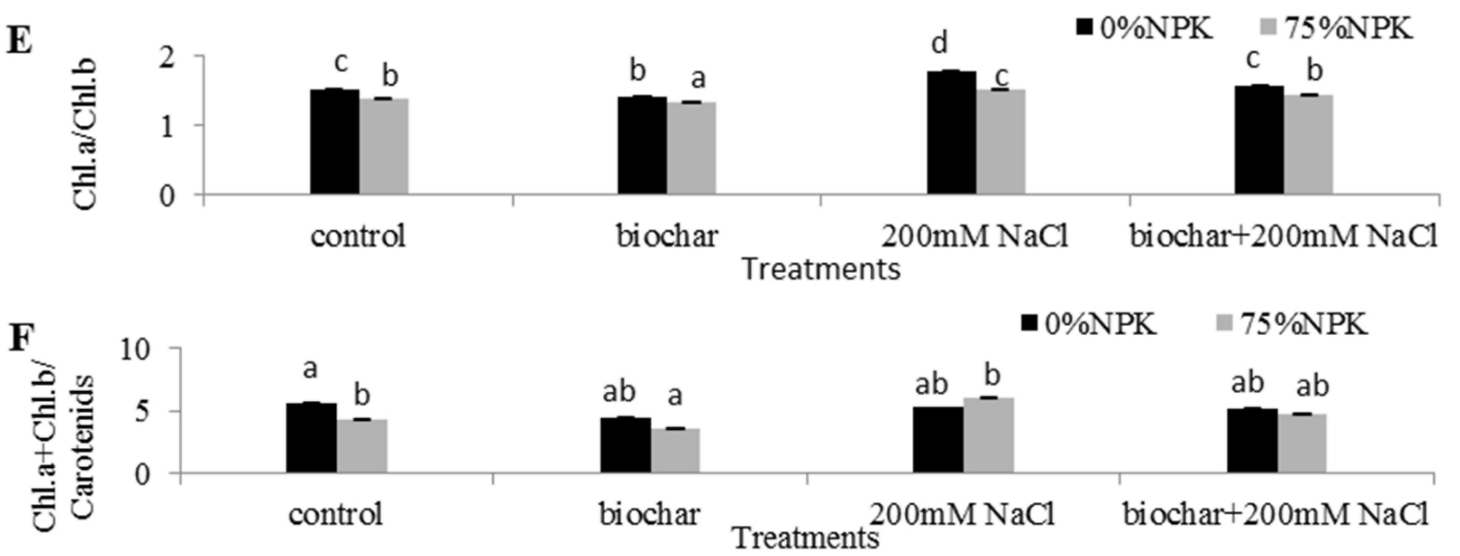

\begin{tabular}{lccc}
\hline Parameters & L.S.D & F-value & Significance \\
\hline Photosynthetic efficiency & 0.05 & 70.89 & $* *$ \\
Chl. $a$ & 0.56 & 28.88 & $* *$ \\
Chl. $b$ & 0.51 & 34.79 & $* *$ \\
Carotenoids & 0.54 & 18.76 & $* *$ \\
Chl. $a$ / Chl. $b$ & 0.06 & 38.37 & $* *$ \\
Chl. $a+$ Chl. $b$ Carotenoids & 1.24 & 3.57 & $*$ \\
\hline
\end{tabular}

Fig. 1. Effect of biochar alone or mixed with NPK (75\%) on the photosynthetic activity (A), Chl. $a$ (B), Chl. $b$ (C), carotenoids (D), Chl. $a / C h l . b$ ratio $(E)$ and $(C h l . a+C h l . b) /$ carotenoids ratio (F) of 21-day-old seedlings of Vigna unguiculata (L.) grown in clay-sandy soil (2:1 w/w) under the effect of salinity stress $(200 \mathrm{mM} \mathrm{NaCl})$ [Values are means of three replicates $\pm \mathrm{SD}$, different letters indicate statistically significant differences $(\mathrm{P} \leq 0.05)]$. 
The results show that salinity stress $(200 \mathrm{mM}$ $\mathrm{NaCl}$ ) led to a highly significant reduction in photosynthetic efficiency $(\mathrm{Fv} / \mathrm{Fm})$ recorded with a percentage $38.7 \%$, compared to control. On the other hand, application of biochar to the soil resulted in a remarkable increase in photosynthetic activity, compared to control, where the percentage of increase was $17.2 \%$, compared with untreated seedlings. Data also showed that application of chemical fertilizer ( $75 \%$ NPK) induced a significant increase in photosynthetic activity with a percentage of $17.74 \%$, compared with control. On the other hand, the percentage of reduction in the photosynthetic activity under salinity stress with the addition of NPK (75\%) was $32.9 \%$ whereas, after application of biochar, the percentage of the activity recorded an increase with a percentage $30 \%$, compared with salinity stressed seedlings treated with NPK (75\%).

\section{Photosynthetic pigments}

The results in Fig. 1 revealed that salinity stress caused a highly significant decline in Chl. $a$, Chl. $b$ and carotenoid contents. The percentages of reduction were $21 \%, 33 \%$ and $21 \%$, respectively, compared to control. Furthermore, salinity caused a significant reduction in the ratio of Chl. $a+\mathrm{Chl} . b /$ Carotenoids by $5 \%$, compared with control. On the other hand, the ratio of Chl. $a / b$ showed a highly significant increase $(8 \%)$ under salinity stress, compared with control.

On the other hand, application of biochar to the soil caused reduction in the negative effects induced by salinity on photosynthetic pigments, compared with the stressed plants. Biochar treatment resulted in a highly significant increase in chlorophyll pigments (Chl. $a$ and Chl. $b$ ) and carotenoid contents by $29 \%, 46 \%$ and $40 \%$, respectively, compared with the control plants. It could be observed that treatment with biochar as a soil amendment effectively increased all the photosynthetic pigments (Chl. $a$, Chl. $b$ and carotenoids) under salinity stress in presence of $75 \%$ NPK, relative to the control values.

\section{Antioxidant enzyme activities and ascorbate content}

The results presented in Fig. 2 showed significant increase in POX, CAT and SOD activities under salinity stress $(200 \mathrm{mM} \mathrm{NaCl})$, where their activities reached $80 \%, 50 \%$ and $30.86 \%$, respectively relative to the control at $0 \%$ NPK. Their activities reached $35.9 \%, 65.6 \%$ and
$42.4 \%$, respectively relative to the control at the same level of $\mathrm{NaCl}$ in combination with $75 \% \mathrm{NPK}$.

However, addition of biochar mixed with $75 \%$ NPK under salinity caused a marked reduction in POX, CAT and SOD activities by $32 \%, 40 \%$ and $38.6 \%$, respectively, compared with salt-stressed seedlings.

Figure 3 A shows that salinity stress $(200 \mathrm{mM}$ $\mathrm{NaCl}$ ) caused a remarkable increase in the ascorbic acid content, where it increased by $23.9 \%$ relative to control. However, the application of biochar under salinity stress resulted in a highly significant reduction in the ascorbic acid content by $24.3 \%$, compared to salinity stressed seedlings.

On the other hand, addition of chemical fertilizer (75\% NPK) under salinity caused a nonsignificant reduction in ascorbate content, while application of biochar combined with NPK (75\%) under salinity stress resulted in a highly significant reduction in ascorbate content $(27.4 \%)$, compared with the salt stressed seedlings.

\section{Malondialdehyde (MDA) content}

The results in Fig. $3 \mathrm{~B}$ demonstrate that salinity stress caused a highly significant increase in MDA content (1.6 fold), compared with the control. On the other hand, addition of biochar to the soil led to a pronounced reduction in MDA content than those of the control and the salinity stressed seedlings. Moreover, addition of chemical fertilizer to the soil caused a significant reduction in MDA content $(8.22 \%)$ compared with control, while addition of biochar combined with chemical fertilizer $(75 \%$ NPK) under salinity caused further reduction in MDA content $(65.72 \%)$, compared with salinity stressed plants.

\section{Total soluble protein and carbohydrate content}

Data in Fig. 4 demonstrate that salinity stress $(200 \mathrm{mM} \mathrm{NaCl})$ caused a highly significant increase in total soluble protein content of roots and shoots ( $89 \%$ and $66 \%$, respectively) relative to control. At the same time, total soluble carbohydrates of roots and shoots showed similar trends (Fig. 5) as they recorded increases by $46 \%$ and $47 \%$, respectively compared to control. However, application of biochar as a sole treatment resulted in a highly significant amelioration of the harmful effects induced by salinity stress causing a remarkable reduction in total soluble proteins and total soluble carbohydrate contents of salt-stressed seedlings 
by $35 \%, 34 \%, 29 \%$ and $17 \%$ of the shoot and root, respectively, compared to corresponding controls.

The single treatments of biochar mixed with $75 \%$ NPK under salinity stress caused a highly significant reduction in the shoot and root total soluble proteins and carbohydrates contents, compared with control.

\section{Total soluble amino acids and proline content}

Figures 6 and 7 show the effect of salinity stress on the content of total soluble amino acids and proline of shoot and root of 21-day-old seedlings of Vigna unguiculata (L.). The results show that salinity stress $(200 \mathrm{mM} \mathrm{NaCl})$ caused a highly significant increase in both shoot and root total soluble amino acids by $64 \%$ and $52 \%$, respectively relative to control. In addition, the content of proline of shoot and root was highly increased by $96 \%$ and $47 \%$, respectively relative to the control. However, application of biochar as a sole treatment resulted in a highly significant recovery from the harmful effects of salinity stress at the highest salinity level $(200 \mathrm{mM} \mathrm{NaCl})$, showing remarkable reduction in the content of total soluble amino acids and proline of salt-stressed seedlings by $24 \%, 32 \%$, $47 \%$ and $45 \%$ of the shoot and root, respectively, compared with corresponding controls.
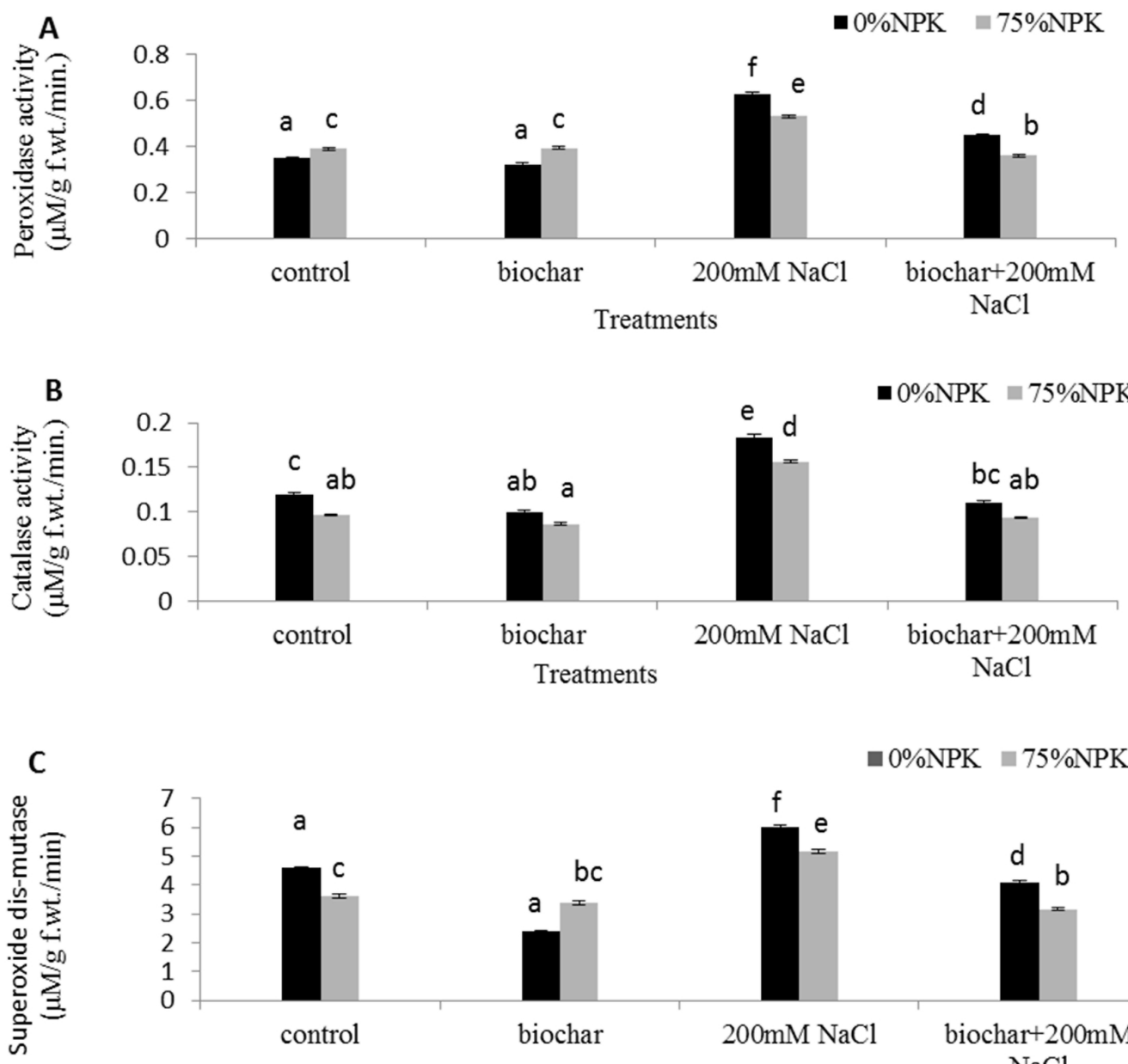

a

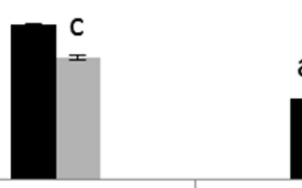

control

biochar

$200 \mathrm{mM} \mathrm{NaCl}$

biochar $+200 \mathrm{mM}$

Treatments

$\mathrm{NaCl}$

\begin{tabular}{lccc}
\hline Parameters & L.S.D & F-value & Significance \\
\hline Peroxidase & 0.02 & 213.3 & $* *$ \\
Catalase & 0.01 & 49.61 & $* *$ \\
Superoxide dismutase & 0.26 & 201.9 & $* *$ \\
\hline
\end{tabular}

Fig. 2. Effect of biochar alone or mixed with NPK (75\%) on peroxidase (A), catalase (B) and superoxide dismutase (C) activities of 21-day-old seedlings of Vigna unguiculata (L.) grown in clay-sandy soil (2:1 w/w) under the effect of salinity stress $(200 \mathrm{mM} \mathrm{NaCl})$ [Values are means of three replicates $\pm \mathrm{SD}$, different letters indicate statistically significant differences $(\mathrm{P} \leq \mathbf{0 . 0 5})]$. 

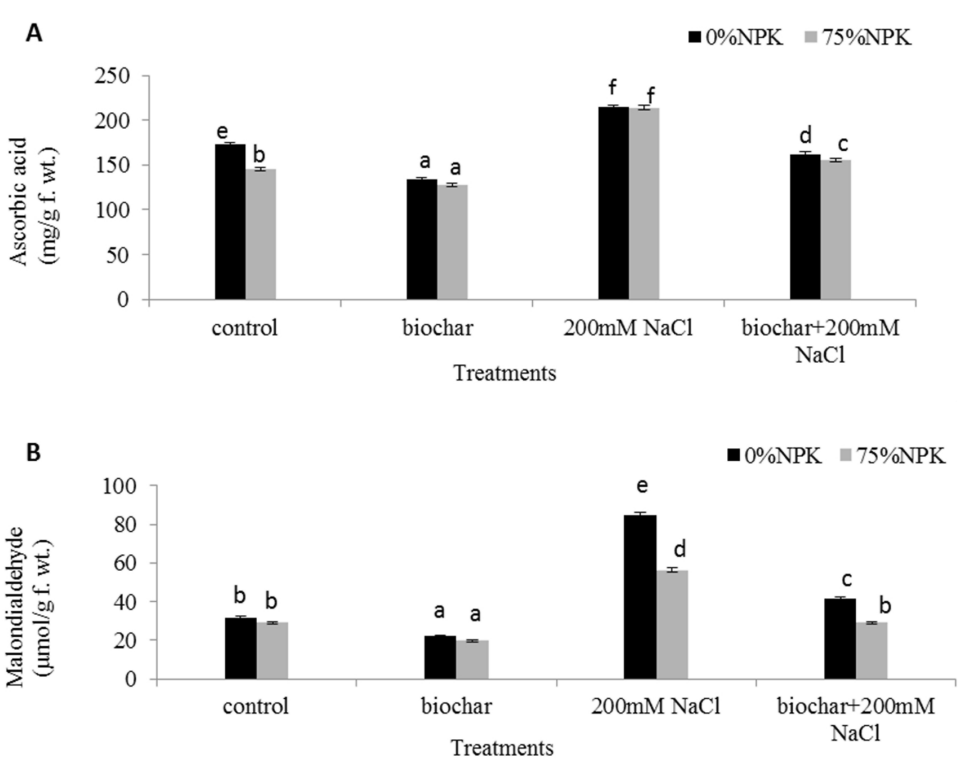

\begin{tabular}{lccc}
\hline Parameters & L.S.D & F-value & Significance \\
\hline $\begin{array}{l}\text { Ascorbic } \\
\text { acid }\end{array}$ & 6.44 & 238.8 & $* *$ \\
MDA & 2.99 & 471.0 & $* *$ \\
\hline
\end{tabular}

Fig. 3. Effect of biochar alone or mixed with NPK (75\%) on the ascorbate (A) and malondialdehyde contents (B) of 21-day-old seedlings of Vigna unguiculata (L.) grown in clay-sandy soil (2:1 w/w) under the effect of salinity stress $(200 \mathrm{mM} \mathrm{NaCl})$ [Values are means of three replicates $\pm \mathrm{SD}$, different letters indicate statistically significant differences $(\mathrm{P} \leq \mathbf{0 . 0 5})]$.
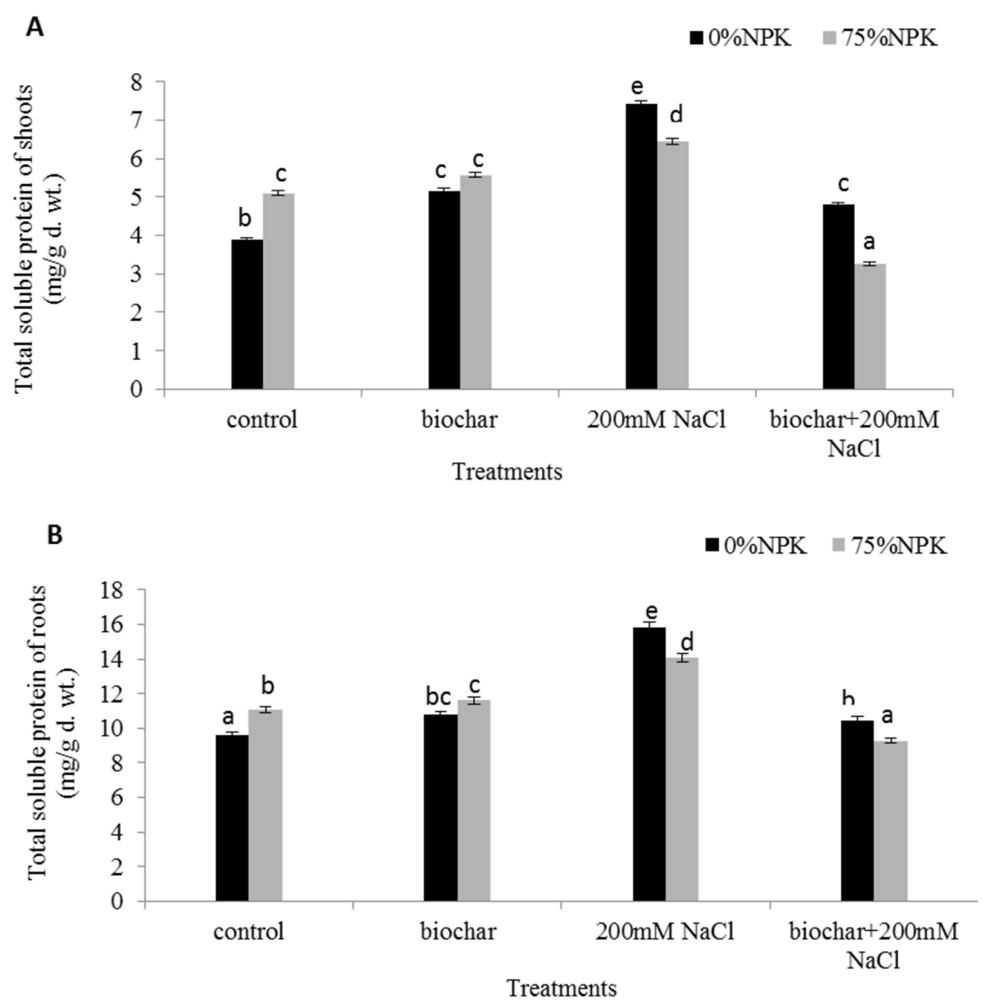

\begin{tabular}{lccc}
\hline Parameters & L.S.D & F-value & Significance \\
\hline $\begin{array}{l}\text { Total soluble } \\
\text { protein of }\end{array}$ & 0.56 & 48.42 & High ** \\
shoots & & & \\
$\begin{array}{l}\text { Total soluble } \\
\text { protein } \\
\text { of roots }\end{array}$ & 0.75 & 79.79 & High ** \\
\hline
\end{tabular}

Fig. 4. Effect of biochar alone or mixed with NPK (75\%) on the total soluble protein content of shoots (A) and roots (B) of 21-day-old seedlings of Vigna unguiculata (L.) grown in clay-sandy soil (2:1 w/w) under the effect of salinity stress $(200 \mathrm{mM} \mathrm{NaCl})$ [Values are means of three replicates $\pm \mathrm{SD}$, different letters indicate statistically significant differences $(\mathrm{P} \leq \mathbf{0 . 0 5})]$. 


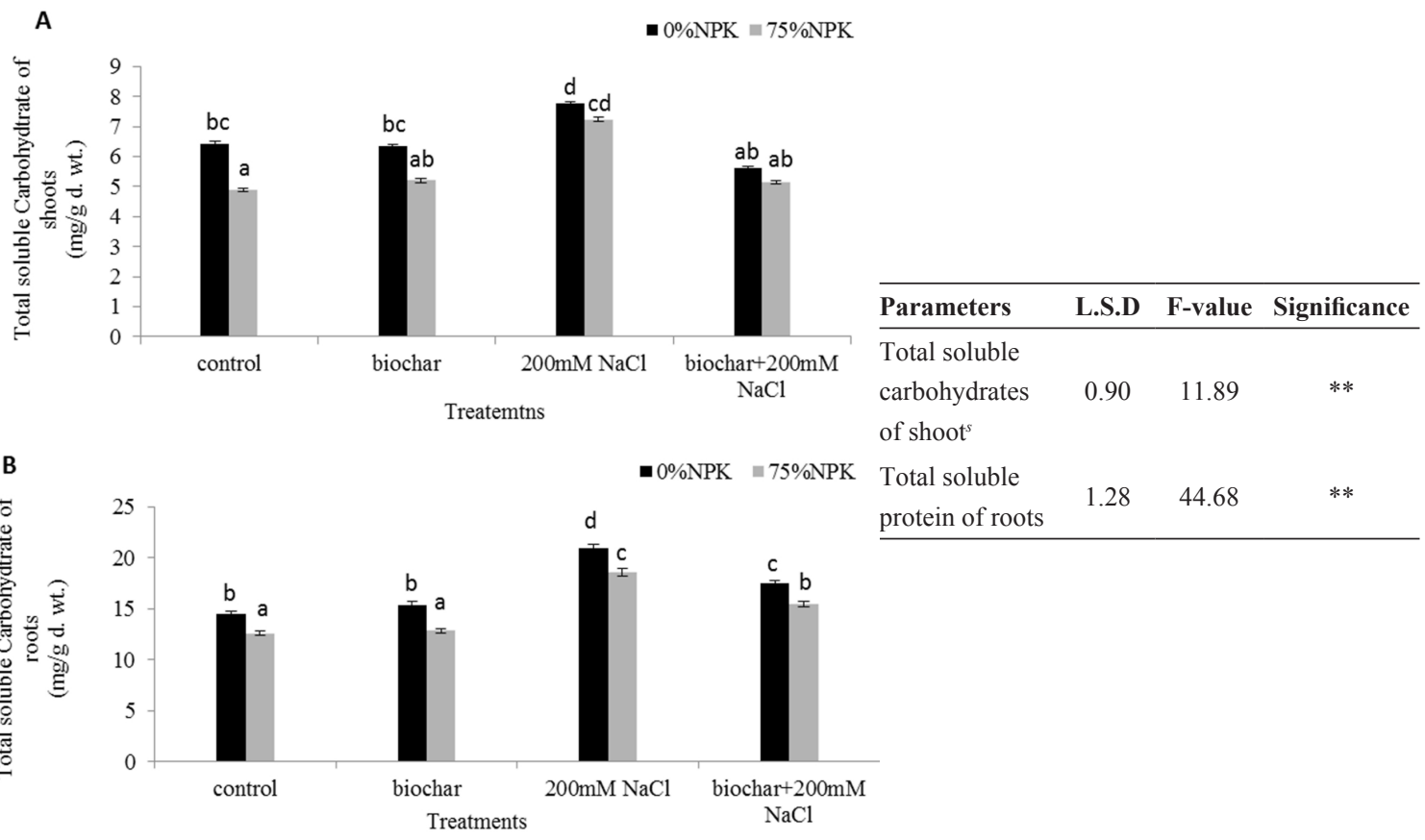

Fig. 5. Effect of biochar alone or mixed with NPK (75\%) on the total soluble carbohydrate content of shoots (A) and roots (B) of 21-day-old seedlings of Vigna unguiculata (L.) grown in clay-sandy soil (2:1 w/w) under the effect of salinity stress $(200 \mathrm{mM} \mathrm{NaCl})$ [Values are means of three replicates $\pm \mathrm{SD}$, different letters indicate statistically significant differences $(\mathrm{P} \leq 0.05)]$.

A

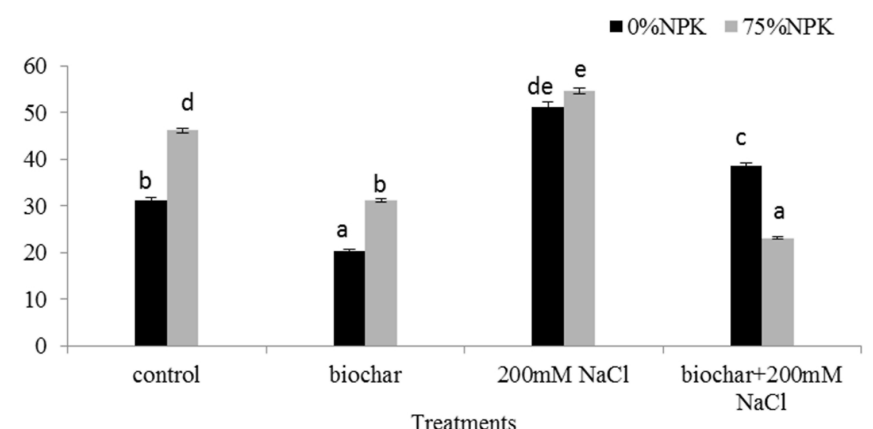

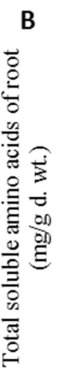

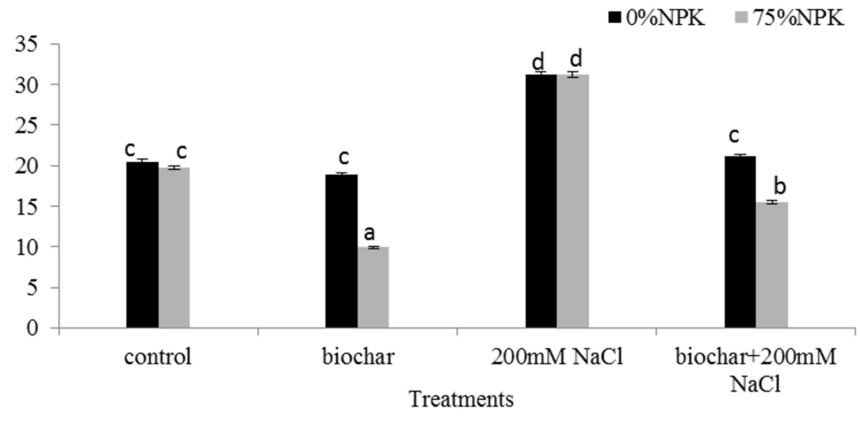

\begin{tabular}{llll}
\hline Parameters & \multicolumn{3}{c}{ L.S.D F-value Significance } \\
\hline $\begin{array}{l}\text { Total soluble } \\
\text { amino acids }\end{array}$ & 5.17 & 54.75 & $* *$ \\
of shoot & & & \\
$\begin{array}{l}\text { Total soluble } \\
\text { amino acids }\end{array}$ & 2.10 & 106.3 & $* *$ \\
of roo $^{\mathrm{t}}$ & & & \\
\hline
\end{tabular}

Fig. 6. Effect of biochar alone or mixed with NPK (75\%) on the total soluble amino acids content of shoots (A) and roots (B) of 21-day-old seedlings of Vigna unguiculata (L.) grown in clay-sandy soil (2:1 w/w) under the effect of salinity stress $(200 \mathrm{mM} \mathrm{NaCl})$ [Values are means of three replicates $\pm \mathrm{SD}$, different letters indicate statistically significant differences $(\mathrm{P} \leq \mathbf{0 . 0 5})]$. 

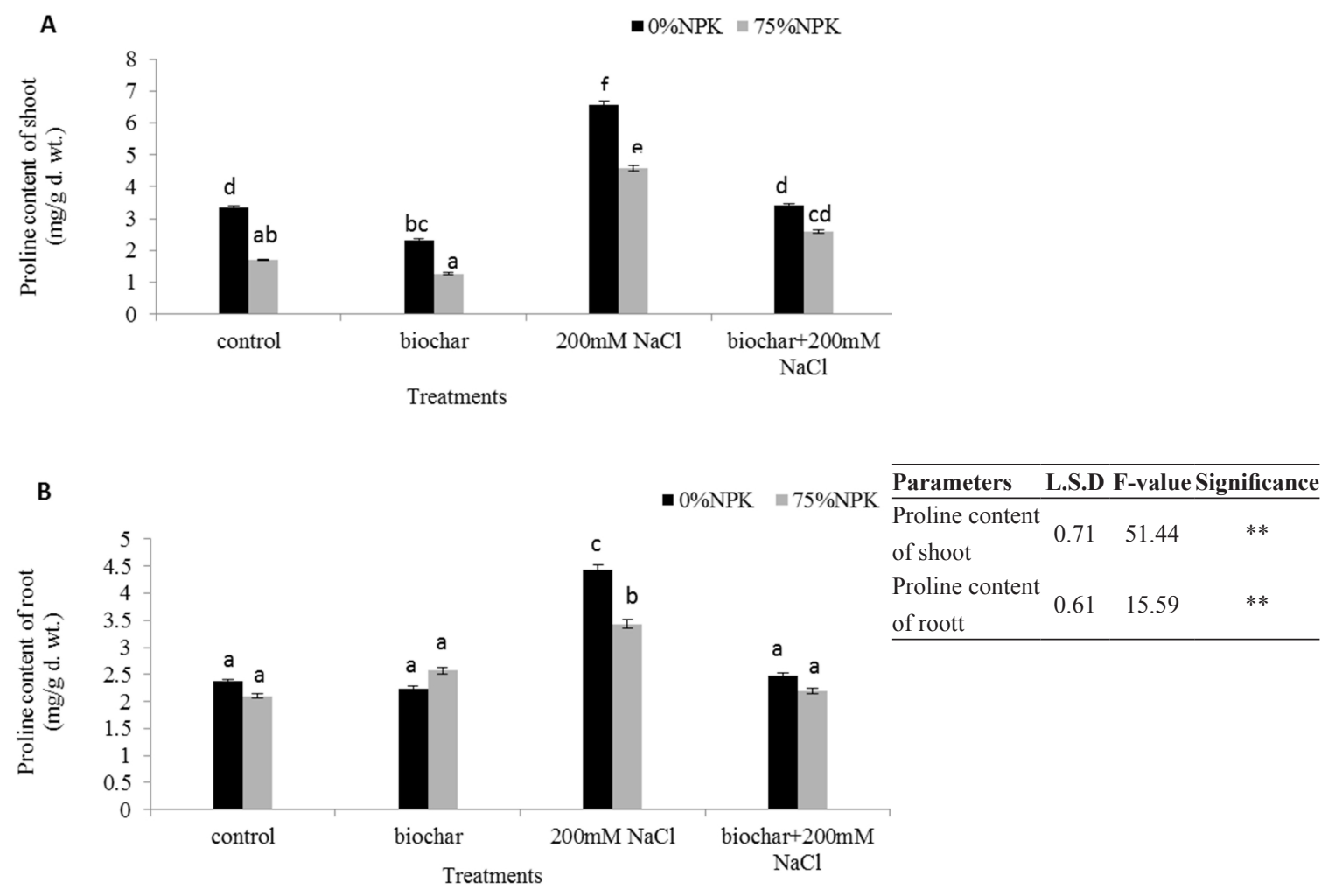

Fig. 7. Effect of biochar alone or mixed with NPK (75\%) on the proline content of shoots (A) and roots (B) of 21-day-old seedlings of Vigna unguiculata (L.) grown in clay-sandy soil (2:1 w/w) under the effect of salinity stress $(200 \mathrm{mM} \mathrm{NaCl})$ [Values are means of three replicates $\pm \mathrm{SD}$, different letters indicate statistically significant differences $(\mathrm{P} \leq 0.05)]$.

The treatments of biochar mixed with $75 \%$ NPK under salinity stress significantly decreased the shoot and root total soluble amino acids and proline contents compared with the control.

\section{Discussion}

Results of the present study showed that salinity stress caused major metabolic disturbances in cowpea seedlings. All measured growth parameters were decreased which are in agreement with the results of Hussein et al. (2017) on faba bean and Kaya et al. (2018) on maize seedlings. Decrease of seedlings length under salinity stress is the result of limitation of water uptake under stress conditions during germination and emergence (Ashraf et al., 2018). Moreover, the adverse effects on plant growth may be due to ion cytotoxicity and osmotic stress that cause nutritional deficiencies, and metabolic imbalance (Akladious \& Hanafy, 2018).

Results showed also that salinity caused reduction in photosynthetic activity and photosynthetic pigments. These data are in accordance with the results of Babar et al. (2014) on fenugreek and Kaya et al. (2018) on maize. Photochemical efficiency of PSII (Fv/ Fm) can be used as a criterion for evaluating plant performance under stressful conditions (Husen et al., 2017). In our study, decline of the $\mathrm{Fv} / \mathrm{Fm}$ value under $\mathrm{NaCl}$ stress suggests that salinity affected some processes related to the photochemistry of photosynthesis. The reduction of Chl. $a$ and Chl. $b$ might be attributed to increase of chlorophyllase that converts chlorophyll into chlorophyllide and phytol and/or damaging of photosynthetic apparatus through blocking pigment-protein complexes (proteins of PSII), which are synthesized in the chloroplasts, and/ or down-regulation of $\mathrm{CO}_{2}$ fixation and stomatal closure (Lin et al., 2016 and Kundu et al., 2018). In addition, the decrease in chlorophyll may be due to osmotic stress that causes the major harm of chloroplast layers and builds the membrane penetrability or loss of membrane uprightness (Tang et al., 2015). 
Salinity led to a significant increase in CAT, POX and SOD activities, ascorbate and MDA contents. These results are in harmony with those of Fazeli et al. (2018) on black cumin (Nigella sativa). Membrane lipids and proteins are deteriorated under salinity that encourages divergence of electrons in transport chains from normal pathways to oxygen reducing ones, leading to overproduction of ROS, which oxidize biomolecules including lipids, proteins, nucleic acids and carbohydrates (Anjum et al., 2014). The inducement of catalase and peroxidase activities indicates the presence of high levels of $\mathrm{H}_{2} \mathrm{O}_{2}$ due to salinity stress (Yousuf et al., 2015). The most efficient role of ascorbic acid is to protect lipids and proteins against salinity or droughtinduced oxidative adversaries ( $\mathrm{Naz}$ et al., 2016). Malondialdehyde is the product of peroxidation of polyunsaturated fatty acids of the plasma membrane; salt stress produces alterations in structure and composition of plasma membrane lipids through increasing the degree of free fatty acids saturation and increasing free sterols, which lead to a decrease in the fluidity of cell membrane (Mansour et al., 2005).

The current results showed highly significant increases in all the assessed organic compounds (total soluble sugars, proteins, amino acids and proline content) of shoots and roots of cowpea under salinity stress. These compatible solutes enhance the tolerance of plants and increase their adaptation to severe stresses (Fahad et al., 2015). These results are in accommodation with those of Pattanagul \& Thitisaksakul (2008) and Kapoor \& Srivastava (2010). These osmotic solutes make osmotic balance, control water influx (reduce efflux) and enable turgor maintenance under salinity (Amirjani, 2011). The remarked increase in protein content may be due to its interaction with cellular macromolecules to detoxify ROS and stabilize their structure or may be due to their protective role of the cell under stress by balancing the osmotic strength of the cytosol with that of the vacuole and the external environment (Tekle \& Alemu, 2016). Proline impacts plant growth and development through its action as metabolic signal mediating metabolite reservoir (Verbruggen \& Hermans, 2008). Moreover, the increase of proline content may be due to its important role in plant protection through the induction of stress-related proteins (Kaur et al., 2017).
In the present work, the improvement of all growth parameters, photosynthetic activity, Chl. $a$, Chl. $b$, carotenoids of cowpea seedlings with biochar addition to the soil may be attributed to improvement of plant growth by mitigating the negative effect of salinity through its high sorption ability (Akhtar et al., 2015). It could be suggested that application of biochar reduces salinity stress by improving soil physicochemical and biological properties directly related to $\mathrm{Na}$ removal such as $\mathrm{Na}$ leaching, $\mathrm{Na}$ adsorption ratio, and $\mathrm{EC}$, as reported by Sun et al. (2016). Moreover, plant nutrient uptake was greatly promoted under the biochar treatment by increasing $\mathrm{K}^{+}$and $\mathrm{K}^{+} / \mathrm{Na}^{+}$ ratio in leaf sap. This result in a close conformity with that reported by Lashari et al. (2015). The incorporation of biochar increased both stomatal aperture and the plants experienced density implying reduced stress as recorded by Akhtar et al. (2014). These results were in agreement with those of Lashari et al. (2015) on maize and Usman et al. (2016) on tomato.

On the other hand, on soil amendment with biochar, the reduced activities of the antioxidant enzymes CAT, POX and SOD and the content of the non enzymatic antioxidant ascorbate might be further markers to amelioration of the hazardous effects of salinity stress. These results were in harmony with those of Lashari et al. (2015) on maize, Farhangi-Abriz \& Torabian (2017) on bean seedlings. The positive effect of biochar application may be attributed to the less production of ROS, MDA and $\mathrm{H}_{2} \mathrm{O}_{2}$ contents that would then enhance the plant tolerance against salinity stress.

\section{Conclusion}

Rice straw biochar could significantly mitigate salinity stress, thus ultimately improve growth, and physiological processes of cowpea plants. This could be mainly attributed to enhancement of photosynthetic activity, photosynthetic pigments and osmolyte levels. These changes were concomitant with decreased antioxidant enzymes activities and contents of both ascorbate and MDA, as compared with corresponding controls. Therefore, incorporation of biochar may be a novel approach for improving crop productivity under salinity stress where it may alleviate the negative impacts of salt stress in crops. In addition, biochar could reduce the required rate of chemical fertilizer NPK by $25 \%$. 


\section{References}

Abbas, T., Rizwan, M., Ali, S., Rehman, M.Z., Qayyum, M.F., Abbas, F., Hannan, F., Rinkleble, J., Ok, Y.S. (2017) Effect of biochar on cadmium bioavailability and uptake in wheat (Triticum aestivum L.) grown in a soil with aged contamination. Ecotoxicology and Environmental Safety, 140, 37-47.

Akhtar, S.S., Li, G., Andersen, M.N., Liu, F. (2014) Biochar enhances yield and quality of tomato under reduced irrigation. Agricultural Water Management, 138, 37-44.

Akhtar, S.S, Andersen, M.N., Liu, F. (2015) Residual effects of biochar on improving growth, physiology and yield of wheat under salt stress. Agricultural Water Management, 158, 61-68.

Akladious, S.A., Hanafy, R.S. (2018) Alleviation of oxidative effects of salt stress in white lupine (Lupinus termis L.) plants by foliar treatment with L- arginine. The Journal of Animal and Plant Science, 28(1), 165-176.

Ali, S., Rizwan, M., Qayyum, M.F., Ok, Y.S., Ibrahim, M., Riaz, M., Arif, M.S., Hafeez, F., AlWabel, M.I., Shahzad, A.N. (2017) Biochar soil amendment on alleviation of drought and salt stress in plants: a critical review. Environmental Science and Pollution Research, 24, 12700-12712.

Allen, S.G., Girmshaw, H.M., Parkinson, J.A., Quarmby, C. (1974) "Chemical Analysis of Ecological Materials". Blackwell Science Publish Oxford, London, 565p.

Amirjani, M.R. (2011) Effect of salinity stress on growth, sugar content, pigments and enzyme activity of rice. International Journal of Botany, 7(1), 73-81.

Anjum, N.A., Aref, I.M., Duarte, A.C., Pereira, E., Ahmad I., Iqbal, M. (2014) Glutathione and proline can coordinately make plants withstand the joint attack of metal (loid) and salinity stresses. Frontiers in Plant Science, 5, 662-665.

Arnon, D.I. (1949) Copper enzymes in isolated chloroplasts. Polyphenol oxidase in Beta vulgaris. Plant Physiology, 24, 1-15.

Ashraf, M.A., Akbar, A., Askari, S.H., Iqbal, M., Rasheed, R., Hussain, I. (2018) Recent advances in abiotic stress tolerance of plants through chemical priming: An overview. In: "Advances in Seed Priming", pp. 51-79.

Babar, S., Siddiqi, E.H., Hussain, I., Bhatti, K.H., Rasheed, R. (2014) Mitigating the effects of salinity by foliar application of salicylic acid in fenugreek. Physiology Journal, 14, 1-6.

Bates, L.S., Waldren, R.P., Teare, I.D. (1973) Rapid determination of free proline for water-stress studies. Plant Soil, 39, 205-207.

Beauchamp, C. and Fridovich, I. (1971) Superoxide dismutase, improved assays and an assay applicable to acrylamide gels. Analytical Biochemistry, 44, 276-287.

Beyer, W.F. and Fridovich, I. (1987) Assaying for superoxide dismutase activity: Some large consequences of minor changes in conditions. Analytical Biochemistry, 161, 559-566.

Blume, L.J. (1990) "Handbook of Methods for Acid Deposition Studies Laboratory Analyses for Soil Chemistry". EPA/600/4-90/023. U.S. Environmental Protection Agency, Las Vegas, NV.

Bradford, M.M. (1976) A rapid and sensitive method for the quantification of microgram quantities of protein utilizing the principle of protein dye binding. Analytical Biochemistry, 72 (1-2), 248-254.

Dubois, M., Gilles, K., Hamilton, J., Rebers, P., Smith, F. (1956) Colorimetric method for determination of sugars and related substances. Analytical Chemistry, 28, 350-356.

Fahad, S., Hussain, S., Matloob, A., Khan, F.A., Khaliq, A., Saud, S., Faiq, M. (2015) Phytohormones and plant responses to salinity stress. Plant Growth Regulation, 75(2), 391-404.

Farhangi-Abriz, S., Torabian, S. (2017) Antioxidant enzyme and osmotic adjustment changes in bean seedlings as affected by biochar under salt stress. Ecotoxicology and Environmental Safety, 137, 64-70.

Fazeli, A., Zarei, B., Tahmasebi, Z. (2018) The effect of salinity stress and salicylic acid on some physiological and biochemical traits of Black cumin (Nigella sativa L.). Zīst/shināsīi $i$ Giyāhhī-i Irān, 9(4), 69-84. 
Hasanuzzaman, M., Alam, M.M., Rahman, A., Nahar, K., Fujita, M. (2014) Exogenous proline and glycine betaine mediated up-regulation of antioxidant defense and glyoxalase systems provides better protection against salt-induced oxidative stress in two rice (Oryza sativa L.) varieties. Biomed. Research International, 2014, 17.

Heath, R.L., Packer, L. (1968) Photoperoxidation in isolated chloroplasts: I. kinetics and stoichiometry of fatty acid peroxidation. Archives of Biochemistry and Biophysics, 125, 189-198.

Husen, A., Iqbal, M., Aref, I.M. (2017) Plant growth and foliar characteristics of faba bean (Vicia faba L.) as affected by indole-acetic acid under watersufficient and water deficient conditions. Journal of Environmental Biology, 38, 179-186.

Hussein, M., Embialei, A., Husen, A., Aref, I.M., Iqbal, M. (2017) Salinity- induced modulation of plant growth and photosynthetic parameters in faba bean (Vicia faba) cultivars. Pakistan Journal of Botany, 49(3), 867-877.

Kapoor, K., Srivastava, A. (2010) Assessment of salinity tolerance of Vigna mungo var.Pu-19 using ex vitro and in vitro methods. Asian Journal of Biotechnology, 2(2), 73-85.

Kato, M., Shimizu, S. (1987) Chlorophyll metabolism in higher plants. VII-chlorophyll degradation in senescing tobacco leaves; phenolic dependent peroxidative degradation. Canadian Journal of Botany, 65(4), 729-735.

Kaur, D., Grewal, S., Kaur, J., Singh, S. (2017) Differential proline metabolism in vegetative and reproductive tissues determine drought tolerance in chickpea. Biologia Plantarum, 61(2), 359-366.

Kaya, C., Akram, N.A., Ashraf, M., Sonmez, O. (2018) Exogenous application of humic acid mitigates salinity stress in maize (Zea mays L.) plants by improving some key physico-biochemical attributes. Cereal Research Communications, 46(1), 67-78.

Kundu, P., Gill, R., Ahlawat, S., Anjum, N.A., Sharma, K.K., Ansari, A.A., Gill, S.S. (2018) Targeting the redox regulatory mechanisms for abiotic stress tolerance in crops. In: "Biochemical, Physiological and Molecular Avenues for Combating Abiotic Stress Tolerance in Plants", Wani S.H. (Ed.), pp. 151-220. Academic Press.
Lashari, M.S., Ye, Y., Ji, H., Li, L., Kibue, G.W., Lu, H., Zheng, J., Pan, G. (2015) Biochar manure compost in conjunction with pyroligneous solution alleviated salt stress and improved leaf bioactivity of maize in a saline soil from central China: A 2 year field experiment. Journal of the Science of Food and Agriculture, 95, 1321-1327.

Lee, Y.P., Takahashi, T. (1966) An improved colorimetric determination of amino acids with the use of ninhydrin. Analytical Biochemistry, 14, 71-77.

Lehmann, J., Joseph, S. (Eds.) (2015) "Biochar for Environmental Management: Science, Technology and Implementation". $2^{\text {nd }}$ ed. Routledge, London and NewYork.

Lin, Y.P., Wu, M.C., Charng, Y.Y. (2016) Identification of a chlorophyll dephytylase involved in chlorophyll turnover in Arabidopsis. The Plant Cell, 28(12), 2974-2990.

Mansour, M.M.F., Salama, K.H.A., Ali, F.Z.M., Abou Hadid, A.F. (2005) Cell and plant responses to $\mathrm{NaCl}$ in Zea mays L. cultivars differing in salt tolerance. General and Applied Plant Physiology, 31, 29-41.

Naz, H., Akram, N.A., Ashraf, M. (2016) Impact of ascorbic acid on growth and some physiological attributes of cucumber (Cucumis sativus) plants under water-deficit conditions. Pakistan Journal of Botany, 48, 877-883.

Nelson, D.W., Sommers, L.E. (1996) Total carbon, organic carbon and organic matter. In: "Methods of Soil Analyses, Part 3, Chemical Methods", Sparks, D.L. (Ed.), pp. 961-1010. Soil Science Society of America, Madison, WI, USA.

Oser, B. (1979) "Hawk's Physiological Chemistry", $15^{\text {th }}$ ed., McGrow Hill Publish. Company, New York.

Pattanagul, W., Thitisakul, M. (2008) Effect of salinity stress on growth and carbohydrate metabolism in three rice (Oryza sativa L.) cultivars differing in salinity tolerance. Indian Journal of Experimental Biology, 46, 736-742.

Snedecor, G.W., Cochran, W.G. (1980) Factorial experiments. In: "Statistical Methods", pp. 298333. Iowa State University Press, Ames, IA., USA.

Sun, J., He, F., Shao, H., Zhang, Z., Xu, G. (2016) 
Effects of biochar application on Suaeda salsa growth and saline soil properties. Environmental Earth Sciences, 75, 1-6.

Tang, H., Hu, Y.Y., Yu, W.W., Song, L.L., Wu, J.S. (2015) Growth, photosynthetic and physiological responses of Torreya grandis Trees, 29(4), 10111022.

Tekle, A.T., Alemu, M.A. (2016.) Drought tolerance mechanisms in field crops. World Journal of Biology and Medical Sciences, 3(2), 15-39.

Usman, A.R.A., Al-Wabel, M.I., Abdulaziz, A.H., Mahmoud, W.A., El-Naggar A.H., Ahmad, M., AlFaraj, A.A.O. (2016) Cono carpus biochar induces changes in soil nutrient availability and tomato growth under saline irrigation. Pedosphere, 26, 27-38.

Verbruggen, N., Hermans, C. (2008) Proline accumulation in plants: A review. Amino Acids, 35(4), 753-759.
Yousuf, P.Y., Ahmad, A., Hemant, M., Ganie, A.H., Iqbal, M., Aref, I.M. (2015) Potassium and calcium application ameliorates growth and oxidative homeostasis in salt- stressed Indian mustard (Brassica juncea) plants. Pakistan Journal of Botany, 47(5), 1629-1639.

Yun, P., Xu, L., Wang, S.S., Shabala, L., Shabala, S., Zhang, W.Y. (2018) Piriformospora indica improves salinity stress tolerance in Zea mays L. plants by regulating $\mathrm{Na}^{+}$and $\mathrm{K}^{+}$loading in root and allocating $\mathrm{K}+$ in shoot. Plant Growth Regulation, 86(2), 323-331.

Zong, Y., Xiao, Q., Lu, S. (2016) Acidity, water retention and mechanical physical quality of a strongly acidic ultisol amended with biochars derived from different feed stocks. Journal of Soils and Sediments, 16, 177-190.

Zunigam, G., Argandona, V.H., Corcuera, L.J. (1989) Distribution of glycine betaine and proline in water stressed and unstressed barley leaves. Phytochemistry, 28, 419-420.

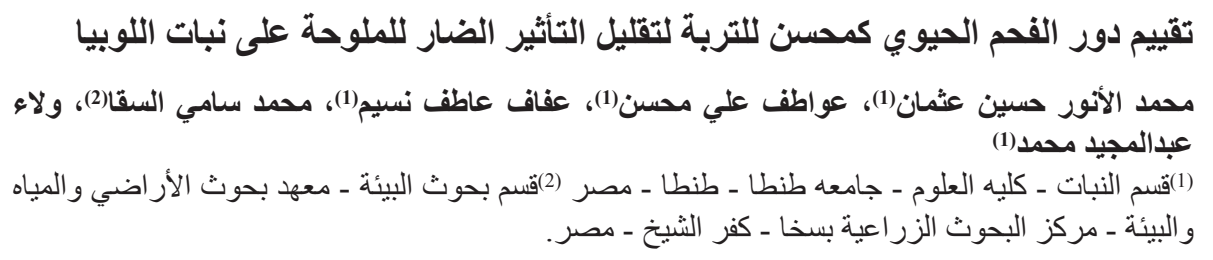

تعتبر الملوحة واحدة من أهم أنواع الإجهاد غير الحيوي التي تقلل من إنتاجيه العديد من النباتات. وقد استهدف

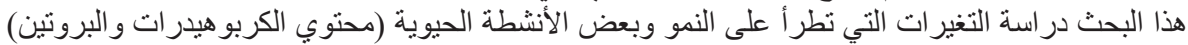

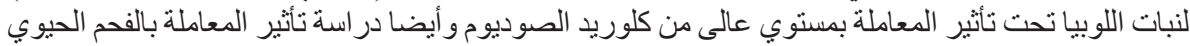

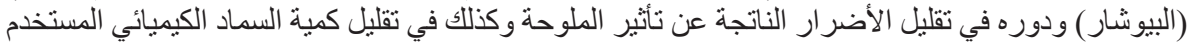

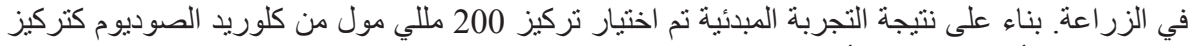

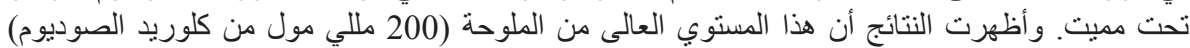
سبب إنخفاضا معنويا في نسبة الإنبات بنسبه $54 \%$ و ونقص في أطو ال الجذور و السيقان للبادر ات بنسبه

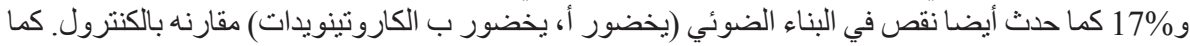

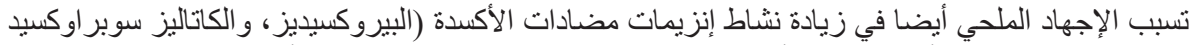

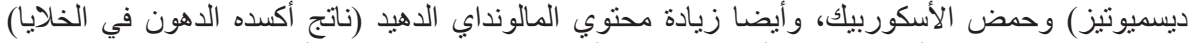

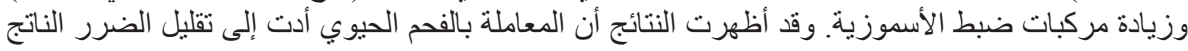

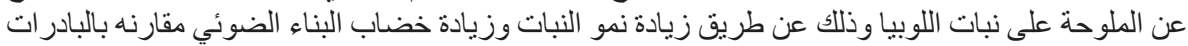

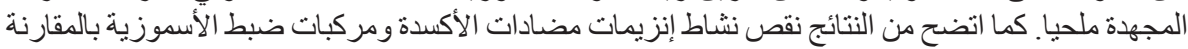

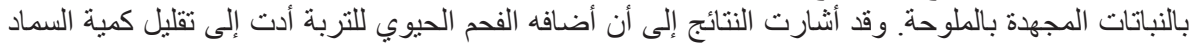

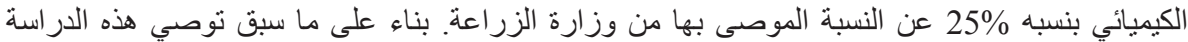
باستخدام الفحم الحيوي مضافا إلى 75\% فقط سماد كيميائي لتقليل الأثر الناتج عن الملوحة في نبات اللوبيا. 